\title{
Significance of Research Career for Neurosurgeons : Development of Brain Tumor Biology through Translational Research
}

\author{
Kensuke Tateishi, M.D., Ph.D., and Tetsuya Yamamoto, M.D., Ph.D. \\ Department of Neurosurgery, Yokohama City University School of Medicine
}

Medical science, including neurosurgical science, has been advanced by basic and clinical research. Unfortunately, the number of Japanese medical doctors choosing a research career has decreased in the past decade. However, the perspectives and experiences gained through basic and clinical research are expected to enhance clinical abilities. In addition, there are numerous things to learn through research experience. Herein, we discuss how research careers are important for clinical physicians. In addition, we present a brain tumor study as an example to show how basic research can contribute to clinical practice.

(Received January 6, 2021 ; accepted January 28, 2021)

Key words : research career, brain tumor, neurosurgery

Jpn J Neurosurg（Tokyo） $30: 280-286,2021$

\section{はじめに}

普段臨床に関わっている若手脳神経外科医にとって, 研究とは何のために行うものなのであろうか. 大学とい う研究・教育機関に所属している関係上, 学生や研修医, 若手脳神経外科医などから質問を受けることがある。彼 らに逆に研究を志す動機について問うと, 臨床とは異な る視点で仕事がしてみたいといったことに加えて, 学位 取得のため, 将来のキャリアを構築するうえでの必要 性, 海外留学のためのステップとして必要, などといつ た回答を得ることも多い.これらの動機は研究を自己実 現のための 1 つの手段として捉えていることを反映して いるものもあり，それ自体は否定されることではない。 一方で臨床医（脳神経外科医）にとっての医学研究を行 う真の目的は何であろうか. 脳神経外科医と基礎研究者
の両立を目指している立場より, 筆者らが考える医学研 究の目的について考察を図りたい. 同時に研究成果がど のように臨床の発展につながるか, 自らの研究を交えつ つ脳腫瘍研究を例に提示する。

\section{研究キャリアを通じて筆者が感じたこと}

筆者 (KT) が脳神経外科医となった動機は, 脳卒中な ぞの救急疾患に対するやりがい, また治療が奏功した際 に得られた達成感に共感したことであった。このような 思いから臨床医のトレーニングを開始し, 卒後 10 数年 は臨床 1 本で活動してきた。しかし糿余曲折を経て脳腫 瘍䛦療を中心とした臨床医と基礎研究者というキャリア (臨床研究者)を歩んでおり, 当初想像した自分とは異な る立ち位置での活動となっている。自身が特に悪性脳腫

\footnotetext{
連絡先：立石健祐，＝236-0004 横浜市金沢区福浦 3-9 横浜市立大学大学院医学研究科脳神経外科学

Address reprint requests to: Kensuke Tateishi, M.D., Ph.D., Department of Neurosurgery, Yokohama City University School of Medicine, 3-9 Fukuura, Kanazawa-ku, Yokohama-shi, Kanagawa 236-0004, Japan
} 
瘍をサブスペシャリティとした経緯は，モニタリング技 術やイメージング技術を駆使することで, 機能温存と広 範囲切除の両立を達成することを目指すという, 外科医 の視点から生まれたものであった。しかしながら病変の 最大限切除を図っても早期に局所・遠隔再発するなどの 困難な経験を重ねた。このことから脳腫瘍の治療成績を 向上させるためには病気の本質を知るための知識の習得 が不可欠と考元, 基礎研究の領域に足を踏み入れること となった。たとえば当時, IDH1 変異などといった単語 は知っていても，この遺伝子異常がどのように病気に関 わるかなど, 本質を深く理解しないで臨床経験を重ねて きたことに, 臨床医としての浅さを自覚するとともにこ の問題に対する解決策を自分なりに模索していたと記憶 している.

このように，筆者の場合は臨床に携わることで見えて きた問題点・課題に向き合うために，基礎研究を自身の エフォートに加えた。一方多くの臨床医同様, 研究に関 してはまったくの素人であり, ピペットなどの器具を 触ったこともなかったし, DNA とは何かなど, 分子生物 学に関する知識はまったく持ち合わせていなかった。た だ幸い臨床医のキャリアは, 臨床上の根本的な疑問点・ 問題点を抽出することに役立つた。いざ基礎研究を始め ると, 毎日繰り返しの単調な仕事も多く, 何のために やっているか理解困難なことも多いものの, 地道な研究 でこそ臨床では検証できないようなことを証明すること が可能となることが理解できた。 何より基礎研究と臨床 は別物ではなく, 両者を同期させることで非常に強い相 乗効果を生み出すことに気づかされた。また幸運だった のは, 基礎研究に携わった早い段階で脳腫瘍に関連する 遺伝子異常の発見や ${ }^{177}$, 遺伝子異常に対する治療法の 提唱など ${ }^{14)-16)}$, 研究面での成功を体験したことがその 後の研究モチベーションの維持につながつた.

このような研究経験を通じて, 仮説の立案方法や仮説 をどのように示すかなど，学会発表や論文を通じて他人 を納得させるために必要な基本的スキルを身につけるこ とができた。何よりも研究経験を通じて, 分子生物学的 的な視点など多角的に病態を考えたうえで臨床にあたる ことが可能になったと考えている．留学期間などを含め 長い時間を基礎研究に費やしたため臨床医としては回り 道をしたが, 研究経験を通じて臨床研究者に必要な洞察 力を獲得できたのではないかと感じており, 結果的に回 り道以上のものを回収できた気がしている。いささか抽 象的ではあるが, 研究経験がない頃の自分と比較する と, 研究者としてのキャリアを多少経験している現在と では，同じょうな術野を見ていても実際に見えているも
のがまったく違うように感じている.

\section{研究のススメ}

このように普段臨床に携わっている若手の脳神経外科 医にとって，研究を行うことは単にキャリアアップのた めの手段としてのみならず，より梁い視点で臨床を考元 るきっかけを得ることが期待できる。研究デー夕を自分 で得る経験を重㸚ることで，既成概念にとらわれない洞

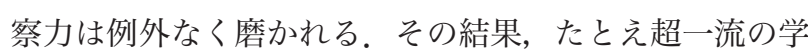
術誌であっても結論がすべて正しいわけではないことが 理解できるようになるであろう。また研究を通じて世界 の最先端に触れることで，世界の広さ，狭さを実感する 機会が得られる。たとえばどのような論文でも世界中の 誰かが読んでいるものであり, 研究成果を通じて思わ女 コネクションづくりにもつながることもある。このよう な経験は広い視点での臨床活動につながり, 結果として 臨床力（総合力）の向上をもたらすものと思われる.

このことからも脳神経外科医のキャリアの中で少なく とも一定期間は研究活動に従事する時間を確保すること が望ましいと個人的には考えている。なお臨床医にとつ て研究は決して特別なものでなく, 疑問・難題を解決し 得る手法として身近なものであることを強調しておきた い. 脳神経外科のような普段緻密な仕事をしていれば, 研究手技などたやすく獲得できるはずである。ただし研 究は思い立つたらある程度早い段階で（無論臨床医とし て生きていくのであれば惰性でズルズルとやるのは好ま しくない）志すのが望ましいのではないかと考元る。 も ちろんきちんとした研究を行うためには大学のような研 究機関の後押しが必要であり, 研究支援体制を組織全体 で構築する必要がある。なお研究は臨床で目指すべき到 達点とは異なり, 独創性を示すうえでも世界を相手とし た競争をしなければならない，そのため一度志したら全 力投球することが望まれ, やる気と継続性, そして突破 力が求められる. 臨床医における研究活動は最終的に臨 床への還元につながることを目指すべきであり, 臨床上 の疑問点を適切な研究素材を通じて明らかにし, その答 えを提唱できることは臨床研究者の最大の強みであると 感じている.

\section{研究者キャリアの課題}

欧米と異なり本邦では研究職ポストに限りがあること から, 大学院や海外留学などで研究期間を過ごしても, その後研究者として活動することが困難な例が数多く存 
e.g., in vitro and in vivo experiments,

biobank system, molecular pathway analysis

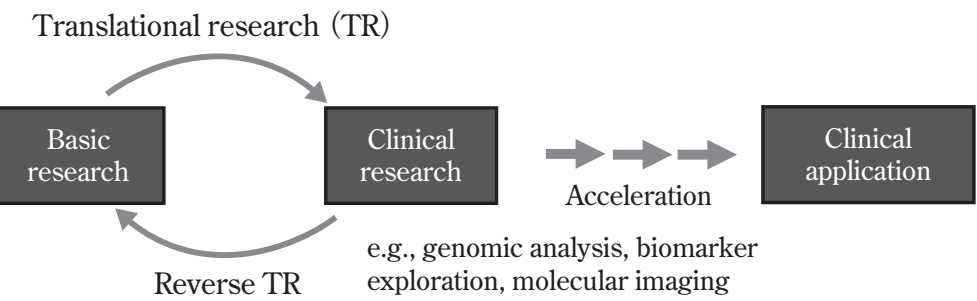

Fig. 1 Scheme of translational and reverse translational research for clinical application

在する。また臨床医である以上研究への携わりは必然的 に遅くなることが多い．たとえば筆者（KT）が脳腫瘍の 基礎研究に携わったのは卒後 12 年目からと遅く, 海外 留学も周りで留学している基礎研究者と比較しても明ら かに遅かった。 上述の理由からも研究を始める時期に関 しては検討の余地があったものと思われる。たとえば研 究助成金や留学助成金などの応募には年齢制限が設定さ れていることが多く, 筆者自身はこの点で大変苦労をし た。このような些細な点でも研究断念を余儀なくされる ケースもあることから, 留学やその後の研究継続を希望 する場合には長期的なキャリアプランを練る必要がある。

なお研究キャリアを継続するためには資金面での高い ハードルが存在する。自身の経験から, 脳神経外科医に 加えて研究者というキャリアを大学院や留学後も実現・ 継続するためには，日々の臨床活動のみならず，研究成 果の論文報告と新しい研究プロジェクトを継続して進め ていく必要があると考えている。 さらには論文を発表し 続けることのみならず，科学技術研究費（科研費）や日 本医療研究開発機構 (AMED), 民間の研究財団からの研 究助成金などの競争的研究資金の獲得に挑戦し続ける必 要がある。いくら研究者としての立ち位置を望んでも, 研究を継続できるか否かは他人が決めることであり, 他 人に研究内容を評価されるよう努め, それを継続・発展 させる必要がある。

\section{脳腫瘍に対するトランスレーショナル研究}

トランスレーショナル（TR）研究，リバース TR 研究 という研究手法が急速に進んでいる。医学に拀ける TR 研究とはラボにおける基礎研究成果を臨床に橋渡しする ことを目指した研究であり, 細胞実験やドラッグスク リーニング試験などによる探索的な研究がこれに相当す る。これに対してリバース TR 研究とは臨床から基礎研 究に橋渡しを図ることを目指しており，たとえば臨床検
体を用いた遺伝子解析やバイオマーカー探索，分子イ メージングなどがこれに相当する．TR 研究とリバース TR 研究を組み合わせることで，たと光ば臨床検体から 得られた遺伝子解析結果を基礎研究に落とし込み，基礎 研究により生物学的機序を解明し，その結果を臨床に還 元することで論理的な治療法の開発を目指すことが可能 となる。このような TR 研究・リバース TR 研究をサイ クル化させ活用することで前臨床研究を促進・成熟さ せ, 臨床応用への加速化を図ることが可能となる (Fig. 1).

創薬を例に挙げると，これまでの研究手法は探索研究 に始まり, 前臨床研究, 各フェーズ試験を経て治療薬剤 として創出されるものの, 非効率性もあり非常に長い時 間を要することが問題であった。たとえば膠芽腫（glioblastoma：GBM）の標準治療薬である temozolomide （TMZ）が開発されてから，GBM に対する治療効果が第 三相試験で示されるまで実に 20 年もの年月を要してい る ${ }^{11) 19)}$.このようなスピード感では急速に進歩する社会 のニーズには到底追いつかず，より効率的な研究手法が 必要とされていた。これに対して前述の TR 研究，リ バース TR 研究手法を活用し，さらには革新的医薬品の 実用化促進（先駆けパッケージ戦略）を加えることで, 意思決定の前倒し, 疾患理解の促進を通じて創薬の効率 アップ，さらには臨床応用の加速化を図ることが可能に なっている，たとえばある遺伝子の異常が腫瘍細胞に及 ぼす影響が明らかになれば，その原理を通じて新しい治 療法を創出することにつながる可能性が生じる.

具体例として神経膠腫（glioma）の発生に関わる重要 な遺伝子異常である $I D H$ 変異は, 2008 年に手作業によ る遺伝子解析（リバース TR 研究）により初めて同定さ れた ${ }^{8)}$ 。乞の後細胞株を用いた TR 研究により, IDH変異 は細胞内に 2-hydroxyglutarate（2-HG）という分子を蓄 積させることで, DNAやヒストンのメチル化を促進させ 腫瘍の発生に重要な役割を果たすことが明らかになっ $た^{2222)}$ 。このように IDH変異が glioma 細胞に及ぼす生物 


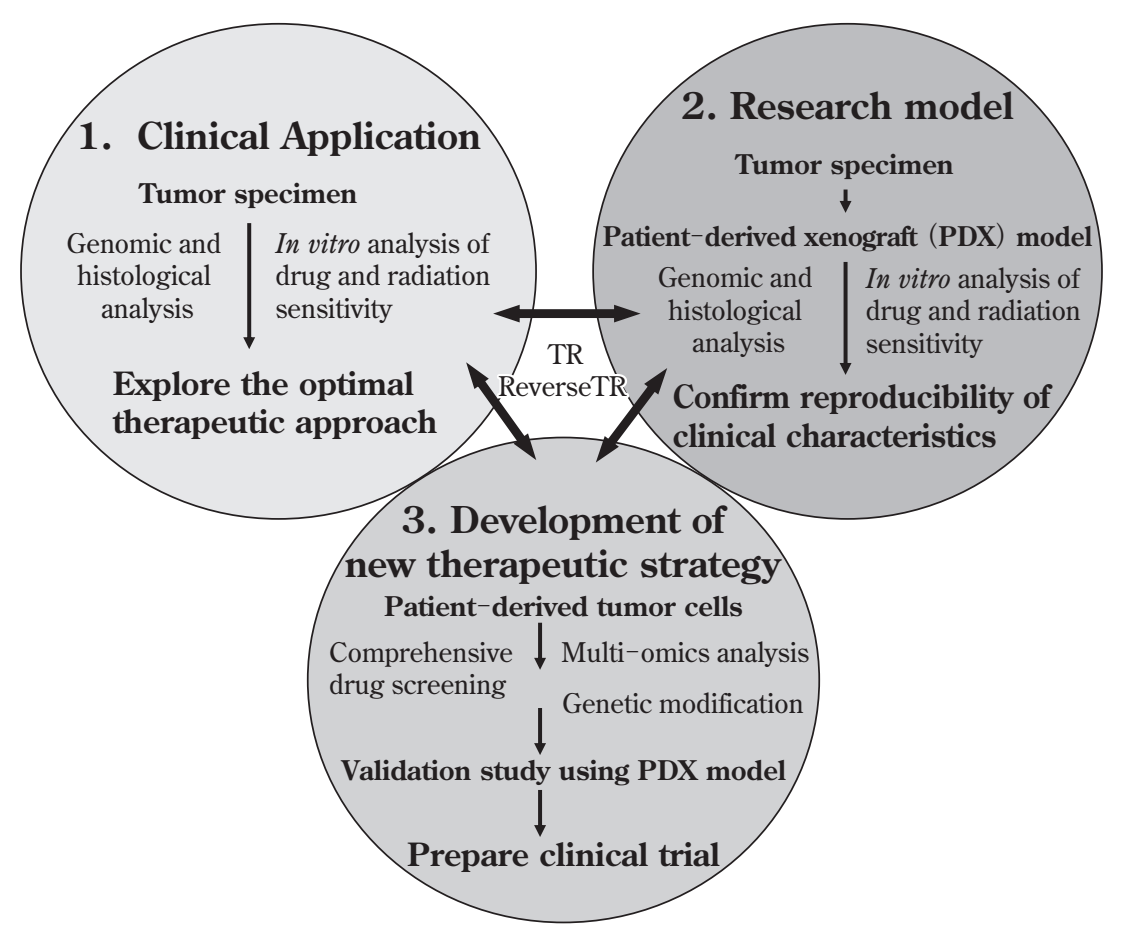

Fig. 2 Research protocol in our lab to develop novel therapeutic strategy for malignant brain tumors

学的機序が急速に解明され, その後変異型 IDH 阻害剤の 開発につながり, 現在複数の阻害剤を用いた治験が世界 各国で行われている4)9)，注目すべきは遺伝子変異の同 定から創薬までに要した期間はわずか 5 年と上述の TMZ の開発と比較すると研究速度が明らかに短縮しているこ とが伺え, これは研究手法の進歩によりもたらされた恩 恵と考えられる。

また, 2019 年に次世代シーケンサーを用いた遺伝子パ ネル検査が保険収載され，遺伝子解析結果に基づくがん ゲノム医療が脳腫瘍治療の分野でも広がりを見せてい る。たとえば遺伝子パネル検査により BRAFV600E 変異 が見出された場合，BRAFや下流分子である MEK を標 的とした分子標的治療が臨床研究への参加や患者申出療 養制度などを通じて可能となっている。一方このような 治療の妥当性の検証や前述の分子標的治療を凌駕する新 しい治療法の開発を行うためには, TR 研究のようなア プローチは重要な役割を果たす。このことからも研究素 材の確保・保存が重要であり, バイオバンクなどの果た す役割は大きいと考える.

\section{われわれの研究室で行っている脳腫瘍研究手法}

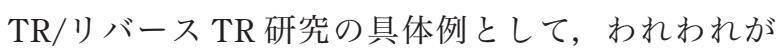

行っている脳腫瘍研究の概要を提示する (Fig. 2). 研究 の具体的な目標として, 脳腫瘍の病態解明とともに, 悪 性脳腫瘍の患者に対する個別的治療法の開発をゴールと して揭げている。これを実現するためには生体外で再現 性の高い前臨床研究を行うことが望まれる。研究モデル として, 中でも患者由来腫瘍組織を異種同所性に免疫不 全マウスに移植して作成する patient-derived xenograft (PDX) モデルは患者腫瘍の組織型や遺伝型を広範に模倣 することに加え, 薬剤感受性や生命予後など臨床所見を 広く再現することが特徴であり, TR 研究素材として活 用する意義は大きい.

このことを踏まえてわれわれは，横浜市立大学ヒトゲ ノム・遺伝子研究等倫理委員会および動物実験委員会承 認のもと（IRB no. A201100004 およびFA19-024）, 手術 にて採取された病変からバイオバンク用の検体を確保す るとともに, 一部の余剩検体を用いて初代培養細胞を作 成し, 薬剤や放射線治療に対する感受性試験を行い, 得 られた結果を臨床へ還元している (TR 研究)。同時に PDX の作成を試みており (TR 研究), 樹立した PDX か ら DNA などを抽出し次世代シークエンサーを活用した 遺伝子解析などを行い, 腫瘍形成に関わる重要な遺伝子 異常を探索する (リバース TR 研究)。さらには, 得られ た情報をもとに, PDX 由来腫瘍細胞を用いて新規分子標 
的治療や治療法の開発を目指した研究を行っている (TR 研究)。たとえば astrocytoma では IDH変異の他 TP53 変 異, ATRX 変異を高頻度に有するが, PDX 樹立例，非樹 立例に対する遺伝子解析を行ったところ, PDX 樹立例で は加えて MET 増幅などの第 3 の遺伝子異常（tertiary alteration）が存在することが判明するとともに，これら の遺伝子異常を有する群の生命予後が不良であることが 明らかになった。またこれらの遺伝子の薬物もしくは RNA 干渉による遺伝子発現の抑制により細胞増殖阻害 効果が認められた。この結果 astrocytoma の増悪機序と 分子標的治療の可能性が見出された ${ }^{21)}$. さらに同様の手 法を用いて oligodendrogliomaについても検証を行つたと ころ, IDH 変異, 染色体 1 番 19 番共欠失, TERT 変異に 加え, PIK $3 C A$ 変異などの遺伝子異常の存在が重要な増 悪要因となること, また分子標的治療の意義を明らかに した ${ }^{17)}$. 他にも中枢神経原発悪性リンパ腫のPDXモデル を通じて, NF-KB 経路の活性化に関わる遺伝子異常が 腫瘍増殖に関わる機構としてきわめて重要であることを $\mathrm{TR}$ 研究，リバース TR 研究を通じて見出した ${ }^{718)}$.

一方で樹立した再現性の高い研究素材を活用すること で, 臨床では検証困難な仮説を立証することが可能とな る. たとえばIDH1 変異 glioma に対する治療標的は IDH1 変異そのものであると考元られてきた。しかしながら IDH1 変異自体は腫瘍形成後には生物学的な役割を有さ ないパッセンジャー変異に変換するとの報告もあり, 実 際に IDH1 変異に対する分子標的剤は代謝産物である $2^{-}$ HG を強力に抑制するものの, 一様な抗腫瘍効果は得ら れていない3)14).この臨床結果はわれわれが細胞株を用 いて行った TR 研究に基づき提唱した理論とおおむね一 致するものである ${ }^{14)}$.これに対して IDH1 変異により生 じた DNA 修復機構変化や代謝変化なども将来の治療標 的候補と考元られている ${ }^{20)}$. たとえばわれわれは生体に 必須の分子である $\mathrm{NAD}+$ 合成経路がIDH1 変異により 変化が生じることを見出した。その結果, $\mathrm{NAD}+$ 合成経 路の律速酵素（NAMPT）を阻害することでNAD+枯渴 を通じて強い細胞毒性が生じることが明らかになっ た ${ }^{14)}$. またこの作用は TMZ と併用することでさらに強 力な抗腫瘍効果が生じることが明らかになった ${ }^{16)}$. 加え て NAD+の消費経路に関連する分子も同様に強い抗腫 瘍効果を示すことが, さらなる TR 研究を通じて見出さ れた ${ }^{5) 6}$. 同時に研究成果を通じて克服すべき課題も浮 き彫りになる。たとえば上述の薬剤 (NAMPT 阻害剤) に は全身的な毒性の問題があり，この問題を克服するため にはNAMPT 阻害剤の局所投与が望ましいと考えられ た。そこで研究を通じて局所投与法を開発したところ
IDH1 変異 glioma マウスモデルに対する低毒性かつ強力 な抗腫瘍効果が得られた ${ }^{10)}$.このような研究成果は, た とえばIDH変異の術中判定法の改良や創薬化が進むこ とで, より個別的な治療法として手術を含めた治療計画 にも影響を与える可能性がある。

これに対し GBM（IDH 野生型）では標準治療は確立 されているものの, 生命予後はきわめて不良である. 残 念ながら生命予後を延長させる分子標的治療は存在せ ず， ウイルス療法や中性子捕捉療法などの腫瘍という敵 全体を治療するような治療法の開発が進んでいる。他 方, われわれは腫瘍内に存在する低酸素環境に着目し, 低酸素環境を ${ }^{64} \mathrm{Cu}-\mathrm{ATSM}$ PET 画像に反映する分子イ メージング法をリバース TR 研究を通じて開発し た ${ }^{12) 13)}$ 。また ${ }^{64} \mathrm{Cu}$ が放出するベー夕線やオージェー電子 による殺細胞効果が存在することが TR 研究を通じて明 らかになった ${ }^{23)}$.これらの研究成果を通じて GBM に対 する低酸素環境を標的とした新規治療法の可能性が見出 され, 現在臨床研究が行われているが, 同時に腫瘍制御 機序を明らかにするためにPDX モデルを用いて検証を 行うなど, 臨床研究と基礎研究を組み合わせて研究を進 めている。

\section{臨床応用に向けた研究の課題}

一方本邦においては, 臨床応用に至る研究開発過程で の高いハードル(死の谷もしくは魔の川と呼ばれるもの) が存在する。これは八イリスクな研究プロセスや莫大な 研究開発費用を必要とすることなどが要因として挙げら れ, 実際 1 つの医薬品が承認を受けるためには 250 程度 のプロジェクトを要するとされている。このことからも 臨床応用に向けた効率を上げる研究手法は重要となる。

上述の PDX のような再現性の高い研究素材を用いた としてもそれはあくまでも類似素材であり, 生体そのも のを $100 \%$ 再現するものではない. たとえば PDX は通常 免疫抑制マウスを用いることからも, 免疫に関連する研 究には適さない.さらには小動物を用いた薬効実験で治 療が有効であるから人間でも有効と言い切れるものでは ない. 基礎研究の結果と臨床研究成績に乘離が生じるの は, このような研究手法に付随する課題もその一因かと 思われる.しかしながら，このような問題が存在するこ とを研究者は常に留意したうえでベンチから臨床への橋 渡し (TR 研究), 逆の臨床からベンチへの橋渡し(リバー ス TR 研究) を駆使した研究を行うことで, 病態の本質 を明らかにすることのみならず，その先の独創的な治療 法の提唱につながることが期待される。これにより研究 
効率は大幅に上がり，ひいては医学応用につながる機会 が高まると思われる。

\section{おわりに}

脳神経外科の研究とキャリアデヴェロップメントとい うテーマに対して, 脳腫瘍研究を例に, 研究の意義や課 題について概説するとともに, 実際の医療への応用を目 指した例として自身らの研究概要を提示した。時代背景 も重なり，とかく臨床志向に傾きがちの若手脳神経外科 医にとって，本稿が少しでも研究意欲を高めるきっかけ になれば幸いである。

\section{謝 辞}

自身のキャリアを考元る機会を与えていただいた故川原 信隆先生 (横浜市立大学), 基礎研究者としてのキャリアを広 げる機会を与えていただいた市村幸一先生（国立がん研究セ ンター), 脇本浩明先生（マサチューセッツ総合病院）をはじ めとする多くの先生方, また現在ラボを支えてくれているス タッフ, 大学院生や, 研究助手をはじめとする関係各位に本 誌を通じて御礼申し上げます。

\section{$\mathrm{COI}$}

著者全員は日本脳神経外科学会への COI 自己申告の登録を 完了しています。本論文に関して開示すべき COI はありませ h.

\section{文 献}

1) Arita $H$, Narita $Y$, Fukushima $S$, Tateishi $K$, Matsushita $Y$, Yoshida A, Miyakita Y, Ohno M, Collins VP, Kawahara N, Shibui S, Ichimura $\mathrm{K}$ : Upregulating mutations in the TERT promoter commonly occur in adult malignant gliomas and are strongly associated with total 1p19q loss. Acta Neuropathol 126: 267-276, 2013.

2) Dang L, White DW, Gross S, Bennett BD, Bittinger MA, Driggers EM, Fantin VR, Jang HG, Jin S, Keenan MC, Marks KM, Prins RM, Ward PS, Yen KE, Liau LM, Rabinowitz JD, Cantley LC, Thompson CB, Vander Heiden MG, Su SM : Cancer-associated IDH1 mutations produce 2hydroxyglutarate. Nature 462:739-744, 2009.

3) Johannessen TA, Mukherjee J, Viswanath P, Ohba S, Ronen SM, Bjerkvig R, Pieper RO : Rapid conversion of mutant IDH1 from driver to passenger in a model of human gliomagenesis. Mol Cancer Res 14: 976-983, 2016.

4) Mellinghoff IK, Ellingson BM, Touat M, Maher E, De La Fuente MI, Holdhoff M, Cote GM, Burris H, Janku F, Young RJ, Huang R, Jiang L, Choe S, Fan B, Yen K, Lu M, Bowden C, Steelman L, Pandya SS, Cloughesy TF, Wen PY : Ivosidenib in isocitrate dehydrogenase 1-mutated advanced glioma. J Clin Oncol 38: 3398-3406, 2020.

5) Miller JJ, Fink A, Banagis JA, Nagashima H, Subramanian M, Lee CK, Melamed L, Tummala SS, Tateishi K, Wakimoto H, Cahill DP : Sirtuin activation targets IDH-mutant tumors. Neuro Oncol 23: 53-62, 2020.

6) Nagashima H, Lee CK, Tateishi K, Higuchi F, Subramanian
M, Rafferty S, Melamed L, Miller JJ, Wakimoto H, Cahill DP : Poly (ADP-ribose) glycohydrolase inhibition sequesters $\mathrm{NAD}+$ to potentiate the metabolic lethality of alkylating chemotherapy in IDH mutant tumor cells. Cancer Discov $10: 1672-1689,2020$.

7) Nakamura T, Tateishi K, Niwa T, Matsushita Y, Tamura K, Kinoshita M, Tanaka K, Fukushima S, Takami H, Arita H, Kubo A, Shuto T, Ohno M, Miyakita Y, Kocialkowski S, Sasayama T, Hashimoto N, Maehara T, Shibui S, Ushijima T, Kawahara N, Narita Y, Ichimura K : Recurrent mutations of CD79B and MYD88 are the hallmark of primary central nervous system lymphomas. Neuropathol Appl Neurobiol 42 : 279-290, 2016.

8) Parsons DW, Jones S, Zhang X, Lin JC, Leary RJ, Angenendt P, Mankoo P, Carter H, Siu IM, Gallia GL, Olivi A, McLendon R, Rasheed BA, Keir S, Nikolskaya T, Nikolsky Y, Busam DA, Tekleab H, Diaz LA Jr, Hartigan J, Smith DR, Strausberg RL, Marie SK, Shinjo SM, Yan H, Riggins GJ, Bigner DD, Karchin R, Papadopoulos N, Parmigiani G, Vogelstein B, Velculescu VE, Kinzler KW : An integrated genomic analysis of human glioblastoma multiforme. Science 321 : 1807-1812, 2008.

9) Rohle D, Popovici-Muller J, Palaskas N, Turcan S, Grommes C, Campos C, Tsoi J, Clark O, Oldrini B, Komisopoulou E, Kunii K, Pedraza A, Schalm S, Silverman L, Miller A, Wang F, Yang H, Chen Y, Kernytsky A, Rosenblum MK, Liu W, Biller SA, Su SM, Brennan CW, Chan TA, Graeber TG, Yen KE, Mellinghoff IK : An inhibitor of mutant IDH1 delays growth and promotes differentiation of glioma cells. Science 340: 626-630, 2013.

10) Shankar GM, Kirtane AR, Miller JJ, Mazdiyasni H, Rogner J, Tai T, Williams EA, Higuchi F, Juratli TA, Tateishi K, Koerner MVA, Tummala SS, Fink AL, Penson T, Schmidt SP, Wojtkiewicz GR, Baig A, Francis JM, Rinne ML, Batten JM, Batchelor TT, Brastianos PK, Curry WT Jr, Barker FG 2nd, Jordan JT, Iafrate AJ, Chi AS, Lennerz JK, Meyerson M, Langer R, Wakimoto H, Traverso G, Cahill DP : Genotypetargeted local therapy of glioma. Proc Natl Acad Sci U S A 115 : E8388-E8394, 2018.

11) Stupp R, Mason WP, van den Bent MJ, Weller M, Fisher B, Taphoorn MJ, Belanger K, Brandes AA, Marosi C, Bogdahn U, Curschmann J, Janzer RC, Ludwin SK, Gorlia T, Allgeier A, Lacombe D, Cairncross JG, Eisenhauer E, Mirimanoff RO ; European Organisation for Research and Treatment of Cancer Brain Tumor and Radiotherapy Groups ; National Cancer Institute of Canada Clinical Trials Group : Radiotherapy plus concomitant and adjuvant temozolomide for glioblastoma. N Engl J Med 352: 987-996, 2005.

12) Tateishi K, Tateishi U, Sato M, Yamanaka S, Kanno H, Murata $\mathrm{H}$, Inoue T, Kawahara $\mathrm{N}$ : Application of $62 \mathrm{Cu}$-diacetyl-bis (N4-methylthiosemicarbazone) PET imaging to predict highly malignant tumor grades and hypoxia-inducible factor-1alpha expression in patients with glioma. AJNR Am J Neuroradiol 34: 92-99, 2013.

13) Tateishi K, Tateishi U, Nakanowatari S, Ohtake M, Minamimoto R, Suenaga J, Murata H, Kubota K, Inoue T, Kawa-

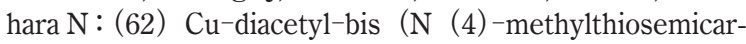
bazone) PET in human gliomas : comparative study with [(18) F] fluorodeoxyglucose and L-methyl-[(11) C $]$ methionine PET. AJNR Am J Neuroradiol $35: 278-284$, 2014.

14) Tateishi K, Wakimoto H, Iafrate AJ, Tanaka S, Loebel F, Lelic 
N, Wiederschain D, Bedel O, Deng G, Zhang B, He T, Shi X, Gerszten RE, Zhang Y, Yeh JJ, Curry WT, Zhao D, Sundaram S, Nigim F, Koerner MVA, Ho Q, Fisher DE, Roider EM, Kemeny LV, Samuels Y, Flaherty KT, Batchelor TT, Chi AS, Cahill DP : Extreme vulnerability of IDH1 mutant cancers to NAD + depletion. Cancer Cell 28: 773-784, 2015.

15) Tateishi K, Iafrate AJ, Ho Q, Curry WT, Batchelor TT, Flaherty KT, Onozato ML, Lelic N, Sundaram S, Cahill DP, Chi AS, Wakimoto $\mathrm{H}: \mathrm{Myc}^{-}$driven glycolysis is a therapeutic target in glioblastoma. Clin Cancer Res 22:4452-4465, 2016.

16) Tateishi K, Higuchi F, Miller JJ, Koerner MVA, Lelic N, Shankar GM, Tanaka S, Fisher DE, Batchelor TT, Iafrate AJ, Wakimoto H, Chi AS, Cahill DP : The alkylating chemotherapeutic temozolomide induces metabolic stress in IDH1mutant cancers and potentiates NAD $(+)$ depletionmediated cytotoxicity. Cancer Res $77:$ 4102-4115, 2017.

17) Tateishi K, Nakamura T, Juratli TA, Williams EA, Matsushita Y, Miyake S, Nishi M, Miller JJ, Tummala SS, Fink AL, Lelic N, Koerner MVA, Miyake Y, Sasame J, Fujimoto K, Tanaka T, Minamimoto R, Matsunaga S, Mukaihara S, Shuto T, Taguchi H, Udaka N, Murata H, Ryo A, Yamanaka S, Curry WT, Dias-Santagata D, Yamamoto T, Ichimura K, Batchelor TT, Chi AS, Iafrate AJ, Wakimoto H, Cahill DP : PI3K/ AKT/mTOR pathway alterations promote malignant progression and xenograft formation in oligodendroglial tumors. Clin Cancer Res 25 : 4375-4387, 2019.

18) Tateishi K, Miyake Y, Kawazu M, Sasaki N, Nakamura T, Sasame J, Yoshii Y, Ueno T, Miyake A, Watanabe J, Matsushita Y, Shiba N, Udaka N, Ohki K, Fink AL, Tummala SS, Natsumeda M, Ikegaya N, Nishi M, Ohtake M, Miyazaki R, Suenaga J, Murata H, Aoki I, Miller JJ, Fujii Y, Ryo A,
Yamanaka S, Mano H, Cahill DP, Wakimoto H, Chi AS, Batchelor TT, Nagane M, Ichimura K, Yamamoto T: A hyperactive RelA/p65-hexokinase 2 signaling axis drives primary central nervous system lymphoma. Cancer Res 80:5330-5343, 2020.

19) Tisdale MJ : Antitumour imidazotetrazines - XI : Effect of 8-carbamoyl-3-methylimidazo [5,1-d]-1,2,3,5-tetrazin-4 (3H) - one [CCRG 81045; $\mathrm{M}$ and B 39831 NSC 362856] on poly (ADP-ribose) metabolism. Br J Cancer $52: 789-792$, 1985.

20) Waitkus MS, Diplas BH, Yan H : Biological role and therapeutic potential of IDH mutations in cancer. Cancer Cell 34: 186-195, 2018.

21) Wakimoto H, Tanaka S, Curry WT, Loebel F, Zhao D, Tateishi K, Chen J, Klofas LK, Lelic N, Kim JC, Dias-Santagata D, Ellisen LW, Borger DR, Fendt SM, Vander Heiden MG, Batchelor TT, Iafrate AJ, Cahill DP, Chi AS : Targetable signaling pathway mutations are associated with malignant phenotype in IDH-mutant gliomas. Clin Cancer Res 20 : 2898-2909, 2014.

22) Xu W, Yang H, Liu Y, Yang Y, Wang P, Kim SH, Ito S, Yang C, Wang P, Xiao MT, Liu LX, Jiang WQ, Liu J, Zhang JY, Wang B, Frye S, Zhang Y, Xu YH, Lei QY, Guan KL, Zhao SM, Xiong Y : Oncometabolite 2-hydroxyglutarate is a competitive inhibitor of alpha-ketoglutarate-dependent dioxygenases. Cancer Cell 19: 17-30, 2011.

23) Yoshii Y, Matsumoto H, Yoshimoto M, Zhang MR, Oe Y, Kurihara H, Narita Y, Jin ZH, Tsuji AB, Yoshinaga K, Fujibayashi $\mathrm{Y}$, Higashi T : Multiple administrations of (64) $\mathrm{Cu}$-ATSM as a novel therapeutic option for glioblastoma: a translational study using mice with xenografts. Transl Oncol 11 : 24-30, 2018.

\section{要}

旨

研究成果がもたらす脳腫湯分子生物学の進展と研究者キャリアの展望

立石 健祐 山本 哲哉

医学の発展は数多くの基礎・臨床研究成果によってもたらされており, 脳神経外科の発展も例外で はない. しかしながらわが国では近年細分化された専門性への志向が高まり, それに反するように研 究者キャリアを選択する人材の伸び悩みが生じている. 一方, 研究を通じて得られる視点や経験など は臨床的能力の底上げにつながることが期待され, また研究を通じて学ぶことも多く存在する. 本稿 では医学研究の目的や研究を通じて習得すべき点, 研究者キャリアの展望などについて筆者自身の経 験を照らし合わせつつ概説する. また医学研究成果がどのように臨床につながるか, 脳腫瘍研究を例 に提示する. 